THE BOX IN THE CORNER 


\section{THE BOX IN THE CORNER}

Television and the Under-fives

A Study by

GWEN DUNN, B.A. 
(C) Gwen Dunn 1977

Softcover reprint of the hardcover 1st edition 1977 978-0-333-19222-1

All rights reserved. No part of this publication may be reproduced or transmitted, in any form or by any means, without permission.

First published 1977 by

THE MACMILLAN PRESS LTD

London and Basingstoke

Associated companies in New York Dublin

Melbourne Johannesburg and Delhi

ISBN 978-0-333-19223-8 ISBN 978-1-349-86149-1 (eBook)

DOI 10.1007/978-1-349-86149-1

This book is sold subject to the standard conditions of the Net Book Agreement.

The paperback edition of this book is sold subject to the condition that it shall not, by way of trade or otherwise, be lent, re-sold, hired out, or otherwise circulated without the publisher's prior consent in any form of binding or cover other than that in which it is published and without a similar condition including this condition being imposed on the subsequent purchaser. 


\section{Contents}

Acknowledgements vii

Foreword $\quad$ ix

Note on References $\quad \mathbf{x}$

I Introduction I

The scope and nature of the study on which the book is based.

2 Television and Language Development

An examination of the ways in which pre-school television programmes might help children to master spoken and then written English.

3 Television as Child Minder

An examination of the ways in which television is at present used in the area covered by this study, and a critical appreciation of networked programmes seen with young children.

4 Teachers' Views

A summary of the views expressed by headteachers and reception teachers in fifty East Anglian schools about preschool television considered in relation to their own problems. A summary of information obtained from $4^{1} 5$ schools about the viewing habits of children who first attended school in the summer of 1973 .

5 Children Watching Television

An account of, and comment on, viewing sessions with children in their own homes or in play groups or day nurseries in the spring and summer of 1973. 
vi Contents

6 Children Remembering Television

An account and analysis of conversations with children in the summer and autumn of 1973 about programmes seen earlier in the year.

7 Conclusions

Some suggestions about necessary research and the role of television in the early education of children, deprived or otherwise.

Bibliography 


\section{Acknowledgements}

My thanks for the opportunity to undertake the study on which this book is based are due to many organisations and individuals, especially the I.B.A., which awarded me a School Teacher Research Fellowship for the year 1973, the West Suffolk Education Authority, which allowed me a year's leave of absence, and the Audio-visual Centre of the University of East Anglia. Without the friendly help and interest of its Director, Malcolm Freegard, his assistant, Dr Palmer, Miss June Lewis and other members of his staff, I would not have found other willing help so readily. I am particularly indebted to the staffs of two day nurseries in Thetford, to play group organisers and leaders, many mothers and a group of students at Keswick Hall College of Education who acted as observers. Hundreds of teachers gave time and effort to help and I am grateful to the Education Authorities of Norfolk, MidEssex and what is now Suffolk for making this possible.

The B.B.C. Audience Research Department, Children's and Schools' Television Departments gave me access to information, and all the help I had time to use. For the same reasons, I thank the Independent Television Companies, Anglia Television, A.T.V., Yorkshire Television, Thames and Granada television. A group of students at the Norwich School of Art gave time during the long vacation to an experiment in story-telling. Dr Joan Tough of the Institute of Education of Leeds University, Mrs Brenda Crowe, National Adviser to the Pre-school Playgroups Association, and Colonel Hallett of the I.B.A. Norwich office made time to answer questions and give advice and help. I am also indebted to Mrs Brook, H.M.I., for putting me in touch with colleagues in other parts of the country, and to Miss Knessens of Sweden who passed on to me the results of research carried out by the Research Department of Sveriges Radio. To Brian Groombridge, Director of the Department of Extra Mural Studies at the University of London, Mr James Porter, Principal of the Berkshire College of Higher Education and to my husband I am very grateful for help and encouragement. 
viii Acknowledgements

The interpretation of the material which I gathered in 1973 is, of course, mine, and is not underwritten necessarily by the I.B.A. or any of the people mentioned above. It is heartening in 1976 , however, to record the amount of time-consuming help given me for no other reason than that the subject of my study concerned the welfare of children. 


\section{Foreword}

It is hard to imagine anyone better qualified to write this book than Gwen Dunn. Writer, broadcaster, member of the I.B.A.'s Educational Advisory Council and of the General Advisory Council of the B.B.C., Mrs Dunn is also a supremely gifted teacher who, as headmistress of a village school in Suffolk, devotes her life to the interests and well-being of young children.

Her book is the outcome of an I.B.A. Fellowship at the University of East Anglia during 1973, a year spent largely in visiting homes, schools and play groups, and interviewing hundreds of parents, teachers, television producers and, most of all, children. Unlike many works of academic provenance, this study offers few statistics, and its conclusions are presented with a total lack of jargon and dogmatism. The great value of Mrs Dunn's work to all those concerned with or about the television young children see lies in the warmth, humour and practical wisdom that Mrs Dunn brings to her vital theme.

Malcolm Freegard

Director of the Audio-visual Centre

University of East Anglia 


\section{Note on References}

References in the text within square brackets relate to the numbered items in the Bibliography 